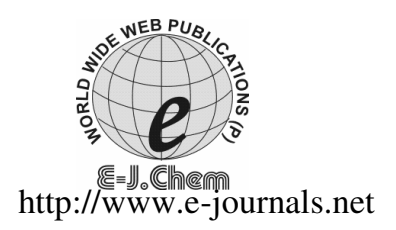

ISSN: 0973-4945; CODEN ECJHAO

E-Journal of Chemistry

2010, 7(4), 1220-1229

\title{
Inhibition of the Corrosion of Mild Steel in Acid Media by Naturally Occurring Acacia Senegal
}

\author{
URVIJA GARG and R K. TAK \\ Department of Chemistry Government College, \\ Ajmer (Rajasthan), India. \\ urvijagarg@gmail.com
}

Received 6 December 2009; Accepted 2 February 2010

\begin{abstract}
The inhibition of corrosion of mild steel in $\mathrm{HCl}$ solution by naturally occurring Acacia senegal has been studied in relation to the concentration of inhibitor and concentration of corrosive medium. It has been observed that the Acacia senegal alcoholic extract acts as a good corrosion inhibitor in hydrochloric acid solution and the adsorption of the extract provides a good protection against mild steel corrosion.
\end{abstract}

Keywords: Corrosion, Inhibitors, Acacia Senegal, HCl, Langmuir adsorption isotherm.

\section{Introduction}

Corrosion is the destructive attack on a metal or metal alloy by chemical or electrochemical reaction with its environment ${ }^{1}$. Corrosion of metal is a major industrial problem that has attracted a lot of investigators in recent years ${ }^{2-4}$. Corrosion inhibitors are of great practical importance, being extensively employed in minimizing metallic waste in engineering materials ${ }^{3}$. Many current corrosion control methods use coating and conversion layers which contain toxic and environmentally hazardous material. There is a great need to find a non toxic replacement that is compatible with current industrial technologies. Well known as non toxic compound and due to their availability and relatively low cost, naturally substances find various applications in many fields. Like tannin, beet $\operatorname{root}^{5,6}$, saponin ${ }^{7}$, tamarind, tealeaves, pomegranate juice peels ${ }^{8,9}$ and the mixture of the later three sapindus, trifolianus and acacia concianna ${ }^{10}$, swertiw aungustefolia ${ }^{11}$ and prosopis juliflora ${ }^{12}$ which have been evaluated as effective corrosion inhibitor.

Mild steel find a variety of application owing to its excellent strength and workability. The corrosion of steel has long been an important problem causing losses in excess of US\$ 100 billion annually worldwide. The corrosion inhibitor of mild steel in different acid media has been studies by various authors ${ }^{13-16}$. In the present work, an attempt has been made to study the influence of varying concentration of constitutes and substitute extracts of 
Acacia senegal the corrosion rate of mild steel in $0.1 \mathrm{~N}$ hydrochloric acid to $5 \mathrm{~N}$ hydrochloric acid. Acacia senegal belongs to the fabaceae family. Its seed are dried and preserved for human consumption ${ }^{17}$. Causing partial destruction of many alkaloids including atropine, hyoscyamine, scopolamine, homatropine, morphine, apomorphine, cocaine and physostigmine, gum acacia might be viewed as a possible antidote. It is pharmaceutically used mainly in the manufacture of emulsions and in making pills and troches, as demulcent for inflammation of the throat or stomach and as masking agent for acrid tasting substance such as capsicum, also as a film forming agent in peel off masks. The alkaloids found in Acacia senegal include less than .1\% DMT and NMT in leaf ${ }^{18-19}$.

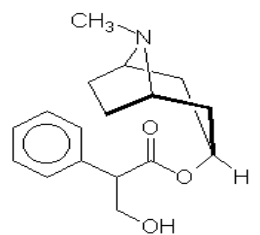

Figure 1. Atropine

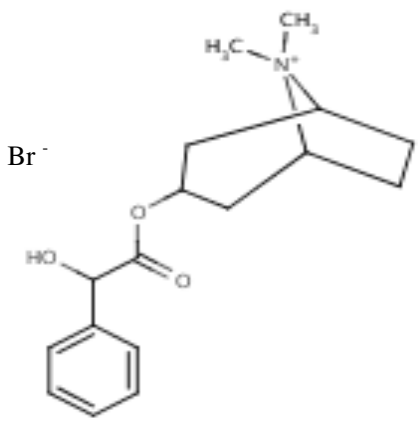

Figure 3. Hyoscyamine<smiles>CNC(=O)Oc1ccc2c(c1)C1(C)CCN(C)C1(C)N2C</smiles>

Figure 2. Esarine (Physostigmine) An acetycholinesterase inhibitior (alkaloid) 2003

A.M. Helmenstine

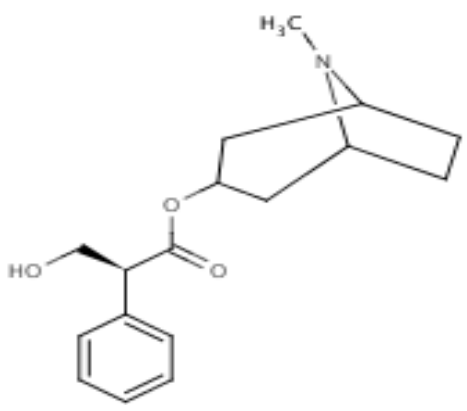

Figure 4. Homatropine

\section{Experimental}

For the mass loss determination, rectangular specimen of mild steel of size $1.5 \times 2.5 \times .025 \mathrm{~cm}$ were so cut from a sheet having chemical composition as carbon $(0.14 \%)$, manganese $(0.32 \%)$, sulphur $(0.05 \%)$, tungsten $(0.02 \%)$ and rest mild steel. To clean the specimens were abraded with various grades of wax coated emery paper $(1 / 0,2 / 0,3 / 0,4 / 0)$ and successively washed with benzene and soap and distilled water and finally with acetone then dried and weight. The metal coupons were than suspended with the help of glass hooks in borosil beakers containing $50 \mathrm{~mL}$ of corrosive electrolyte for complete immersion test. The solution of $0.1 \mathrm{~N}$ to $5 \mathrm{~N} \mathrm{HCl}$ were prepared using doubly distilled water.

The Senegal extract was obtained by dried the parts of plants, then finely powdered and extracted with boiling methanol. The solvent is distilled off and residue treated with inorganic acid. Where, the base is extracted as their soluble salt. The free bases are liberated by the addition of any base and extracted with various solvent $e g$. ether, chloroform, etc. The mixture of base thus obtained is separated by various methods into the individual compound $^{20}$. 
The test specimens were studies for complete immersion test in different acid solution at $298 \pm 1 \mathrm{~K}$ temperatures with and without inhibitor, after removal of the corrosion product. The duration of immersion time is $24 \mathrm{~h}$ and is indicated in respective Tables. After the immersion period the specimen was cleaned carefully as per champion. Corrosion rate (mmpy), inhibition efficiency ( $\eta \%)$, rate constant and half life were calculated from this mass loss data. The results are depicted in respective Table. The inhibitor efficiency $(\eta \%)$ is calculated $\operatorname{as}^{21}$.

$$
\eta \%=100(\Delta \mathrm{Mu}-\Delta \mathrm{Mi} / \Delta \mathrm{Mu})
$$

Where the $\mathrm{Mu}$ is the mass loss of metal in uninhibited acid and Mi; mass loss of metal in inhibited solution. The degree of surface coverage $(\theta)$ can be calculated as

$$
\theta=\Delta \mathrm{Mu}-\Delta \mathrm{Mi} / \Delta \mathrm{Mu}
$$

Where $\theta$ is surface coverage and $\Delta \mathrm{Mu}$ and $\Delta \mathrm{Mi}$ are the mass loss of the metal in uninhibited and inhibited acid. The corrosion rate in miles per year can be obtained by the following equaction ${ }^{22}$.

$$
\text { Corrosion rate }=\frac{\text { mass loss } X 87600}{\text { Area } X \text { time } X \text { density }}
$$

Where mass loss in gram, Area is in of metal surface exposed time is expressed in hours of exposure and metal density is expressed in gram $/ \mathrm{cm}^{3}$.

The corrosion current (i) can be calculated as ${ }^{23}-$

Corrosion current $(\mathrm{i})=$ Corrosion rate $\mathrm{X} \mathrm{F} / \mathrm{n}$

Where $\mathrm{F}$ is faraday (96500) and $\mathrm{n}$ is number of electron. The inhibitive action and the compound will also be investigated by using mylius thermometric method. This involved the immersion of single specimens $(2.5 \times 1.5 \times 0.025 \mathrm{~cm})$ in a reaction chamber containing $50 \mathrm{~mL}$. of solution at initial temperature $298 \pm 0.1 \mathrm{~K}$. Temperature changes were measured at intervals of $5 \mathrm{~min}$ using thermometer with a precision of $0.01 \mathrm{~K}$. The temperature increased slowly at first them rapidly and attained a maximum value before falling. The minimum temperature was recorded the percentage inhibition efficiencies in this case were calculated ${ }^{24}$.

$$
\eta=100\left(\mathrm{RN}_{\text {free }}-\mathrm{RN}_{\mathrm{i}}\right) / \mathrm{RN}_{\text {free }}
$$

Where $\mathrm{RN} i$ and $\mathrm{RN}$ free are the reaction number in the presence and absence of inhibitor respectively and $\mathrm{RN}\left(\mathrm{K} \mathrm{Min}^{-}\right)$is defined as

$$
\mathrm{RN}=(\mathrm{Tm}-\mathrm{To}) / \mathrm{t}
$$

Where Tm and to is the maximum and initial temperature respectively and $t$ is the time required to reach the maximum temperature in minutes.

\section{Results and Discussion}

All the inhibitors have reduced the corrosion rate to a significant extent. Corrosion rate, inhibition efficiency, surface coverage, corrosion current, rate constant, half life with or without inhibitor are show in Tables 1-4.

Effect of concentration- The $\eta \%$ calculated from the mass loss measurement for. $1 \mathrm{~N}$ to $1 \mathrm{~N} \mathrm{HCl}$ solution. It is found that the inhibition efficiency increases with increases of inhibitor concentration for different plant extracts from $0.12 \%$ to $0.6 \%$ from the mass loss data. It was concluded that the plant extracts act as a good inhibitor for mild steel in $\mathrm{HCl}$ solution. Table show that the leaf extract of Acacia senegal has maximum inhibition efficiency. 
Kinetic parameter- From Tables 1-4, the rate constant at 298K show a general decrease with increases inhibitor concentration, inhibitor efficiency, half life of the metal -corrodent-inhibitor system. Similar trend in kinetic data has been reported by several investigators and indicate that a good inhibitor is one that is able to increase the time of conversion of metals to corrosion products. Table show increases in half life when inhibitors are present, which further support the assertion that the natural product are corrosion inhibitors for mild steel in $\mathrm{HCl}$ solution.

Table 1. Effect of extract of different parts of plants Acacia Senegal on mass loss data for corrosion of mild steel in $0.1 \mathrm{~N} \mathrm{HCl}$ at $298 \pm 1 \mathrm{~K}$ Effective area of specimen: $7.50 \mathrm{~cm}^{2}$ Immersion time $24 \mathrm{~h}$

\begin{tabular}{|c|c|c|c|c|c|c|c|}
\hline $\begin{array}{c}\text { Inhibitor } \\
\text { concentration }\end{array}$ & 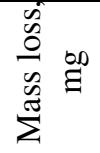 & $\begin{array}{c}\text { Inhibition } \\
\text { efficiency, } \eta \%\end{array}$ & $\begin{array}{c}\text { Surface } \\
\text { coverage } \theta\end{array}$ & 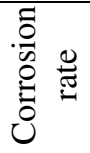 & $\begin{array}{l}\text { Corrosion } \\
\text { current }\end{array}$ & $\begin{array}{c}\text { Rate } \\
\text { constant }\end{array}$ & $\begin{array}{l}\text { Half } \\
\text { life }\end{array}$ \\
\hline Uninhibited & 40.3 & 0.00 & 0.0000 & 2.50 & 80263.88 & 0.0022 & 315.94 \\
\hline \multicolumn{8}{|l|}{ Leaf extract } \\
\hline 0.12 & 16.2 & 59.80 & 0.5980 & 1.00 & 32264.89 & 0.0009 & 798.47 \\
\hline 0.24 & 13.5 & 66.50 & 0.6650 & 0.84 & 26887.40 & 0.0007 & 959.84 \\
\hline 0.36 & 10.1 & 74.94 & 0.7494 & 0.63 & 20115.76 & 0.0005 & 1285.77 \\
\hline 0.48 & 6.7 & 83.37 & 0.8337 & 0.41 & 13344.12 & 0.0004 & 1942.48 \\
\hline 0.60 & 3.9 & 90.32 & 0.9032 & 0.24 & 7767.47 & 0.0002 & 3343.06 \\
\hline \multicolumn{8}{|l|}{ Seed extract } \\
\hline 0.12 & 18.1 & 55.09 & 0.5509 & 1.12 & 36049.04 & 0.0010 & 713.77 \\
\hline 0.24 & 15.3 & 62.03 & 0.6203 & 0.95 & 30472.39 & 0.0008 & 845.93 \\
\hline 0.36 & 12.4 & 69.23 & 0.6923 & 0.77 & 24696.58 & 0.0007 & 1045.73 \\
\hline 0.48 & 10 & 75.19 & 0.7519 & 0.62 & 19916.60 & 0.0005 & 1298.71 \\
\hline 0.60 & 6.8 & 83.13 & 0.8313 & 0.42 & 13543.29 & 0.0004 & 1913.79 \\
\hline \multicolumn{8}{|l|}{ Bark extract } \\
\hline 0.12 & 17.3 & 57.07 & 0.5707 & 1.07 & 34455.71 & 0.0009 & 747.17 \\
\hline 0.24 & 13.7 & 66.00 & 0.6600 & 0.85 & 27285.74 & 0.0007 & 945.70 \\
\hline 0.36 & 11.6 & 71.22 & 0.7122 & 0.72 & 23103.25 & 0.0006 & 1118.42 \\
\hline 0.48 & 8.4 & 79.16 & 0.7916 & 0.52 & 16729.94 & 0.0004 & 1547.67 \\
\hline 0.60 & 6 & 85.11 & 0.8511 & 0.37 & 11949.96 & 0.0003 & 2170.07 \\
\hline \multicolumn{8}{|l|}{ Root extract } \\
\hline 0.12 & 16.5 & 59.06 & 0.5906 & 1.02 & 32862.38 & 0.0009 & 783.80 \\
\hline 0.24 & 13.2 & 67.25 & 0.6725 & 0.82 & 26289.91 & 0.0007 & 981.84 \\
\hline 0.36 & 10.8 & 73.20 & 0.7320 & 0.67 & 21509.92 & 0.0006 & 1201.89 \\
\hline 0.48 & 8 & 80.15 & 0.8015 & 0.50 & 15933.28 & 0.0004 & 1625.47 \\
\hline 0.60 & 4.8 & 88.09 & 0.8809 & 0.30 & 9559.97 & 0.0003 & 2714.68 \\
\hline \multicolumn{8}{|l|}{ Gum extract } \\
\hline 0.12 & 15.3 & 62.03 & 0.6203 & 0.95 & 30472.39 & 0.0008 & 845.93 \\
\hline 0.24 & 11.6 & 71.22 & 0.7122 & 0.72 & 23103.25 & 0.0006 & 1118.42 \\
\hline 0.36 & 9.2 & 77.17 & 0.7717 & 0.57 & 18323.27 & 0.0005 & 1412.36 \\
\hline 0.48 & 6.4 & 84.12 & 0.8412 & 0.40 & 12746.62 & 0.0003 & 2033.92 \\
\hline 0.60 & 3.6 & 91.07 & 0.9107 & 0.22 & 7169.97 & 0.0002 & 3622.34 \\
\hline
\end{tabular}


Table 2. Effect of extract of different parts of plants acacia Senegal on mass loss data for corrosion of mild steel in $0.2 \mathrm{~N} \mathrm{HCl}$ at $298 \pm 1 \mathrm{~K}$, Effective area of specimen: $7.50 \mathrm{~cm}^{2}$ Immersion time $24 \mathrm{~h}$

\begin{tabular}{|c|c|c|c|c|c|c|c|}
\hline $\begin{array}{c}\text { Inhibitor } \\
\text { concentration }\end{array}$ & 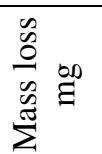 & $\begin{array}{c}\text { Inhibition } \\
\text { efficiency, } \eta \%\end{array}$ & $\begin{array}{l}\text { Surface } \\
\text { coverage, } \theta\end{array}$ & ن & $\begin{array}{l}\text { Corrosion } \\
\text { current }\end{array}$ & $\begin{array}{c}\text { Rate } \\
\text { constant }\end{array}$ & $\begin{array}{l}\text { Half } \\
\text { life }\end{array}$ \\
\hline Uninhibited & 75.3 & 0.00 & 0.0000 & 4.66 & 149971.97 & 0.0042 & 165.12 \\
\hline \multicolumn{8}{|l|}{ Leaf extract } \\
\hline 0.12 & 35.7 & 52.59 & 0.5259 & 2.21 & 71102.25 & 0.0019 & 357.74 \\
\hline 0.24 & 27.3 & 63.75 & 0.6375 & 1.69 & 54372.31 & 0.0015 & 470.41 \\
\hline 0.36 & 22.8 & 69.72 & 0.6972 & 1.41 & 45409.84 & 0.0012 & 564.91 \\
\hline 0.48 & 16 & 78.75 & 0.7875 & 0.99 & 31866.55 & 0.0009 & 808.56 \\
\hline 0.60 & 10.1 & 86.59 & 0.8659 & 0.63 & 20115.76 & 0.0005 & 1285.77 \\
\hline \multicolumn{8}{|l|}{ Seed extract } \\
\hline 0.12 & 34.6 & 54.05 & 0.5405 & 2.14 & 68911.42 & 0.0019 & 369.38 \\
\hline 0.24 & 29.4 & 60.96 & 0.6096 & 1.82 & 58554.79 & 0.0016 & 436.20 \\
\hline 0.36 & 25.6 & 66.00 & 0.6600 & 1.59 & 50986.49 & 0.0014 & 502.20 \\
\hline 0.48 & 21 & 72.11 & 0.7211 & 1.30 & 41824.85 & 0.0011 & 614.05 \\
\hline 0.60 & 15.8 & 79.02 & 0.7902 & 0.98 & 31468.22 & 0.0008 & 818.90 \\
\hline \multicolumn{8}{|l|}{ Bark extract } \\
\hline 0.12 & 33.1 & 56.04 & 0.5604 & 2.05 & 65923.93 & 0.0018 & 386.50 \\
\hline 0.24 & 27.1 & 64.01 & 0.6401 & 1.68 & 53973.98 & 0.0015 & 473.94 \\
\hline 0.36 & 23.3 & 69.06 & 0.6906 & 1.44 & 46405.67 & 0.0013 & 552.61 \\
\hline 0.48 & 17.3 & 77.03 & 0.7703 & 1.07 & 34455.71 & 0.0009 & 747.17 \\
\hline 0.60 & 12 & 84.06 & 0.8406 & 0.74 & 23899.92 & 0.0006 & 1080.86 \\
\hline \multicolumn{8}{|l|}{ Root extract } \\
\hline 0.12 & 33.8 & 55.11 & 0.5511 & 2.09 & 67318.09 & 0.0018 & 378.32 \\
\hline 0.24 & 25.6 & 66.00 & 0.6600 & 1.59 & 50986.49 & 0.0014 & 502.20 \\
\hline 0.36 & 21.8 & 71.05 & 0.7105 & 1.35 & 43418.18 & 0.0012 & 591.21 \\
\hline 0.48 & 16.5 & 78.09 & 0.7809 & 1.02 & 32862.38 & 0.0009 & 783.80 \\
\hline 0.60 & 11.2 & 85.13 & 0.8513 & 0.69 & 22306.59 & 0.0006 & 1158.67 \\
\hline \multicolumn{8}{|l|}{ Gum extract } \\
\hline 0.12 & 31.6 & 58.03 & 0.5803 & 1.96 & 62936.44 & 0.0017 & 405.25 \\
\hline 0.24 & 24.8 & 67.07 & 0.6707 & 1.54 & 49393.16 & 0.0013 & 518.67 \\
\hline 0.36 & 20.3 & 73.04 & 0.7304 & 1.26 & 40430.69 & 0.0011 & 635.51 \\
\hline 0.48 & 15.8 & 79.02 & 0.7902 & 0.98 & 31468.22 & 0.0008 & 818.90 \\
\hline 0.60 & 9.7 & 87.12 & 0.8712 & 0.60 & 19319.10 & 0.0005 & 1339.13 \\
\hline
\end{tabular}

Table 3. Effect of extract of different parts of plants acacia Senegal on mass loss data for corrosion of mild steel in $0.5 \mathrm{~N} \mathrm{HCl}$ at $298 \pm 1 \mathrm{~K}$, Effective area of specimen: $7.50 \mathrm{~cm}^{2}$ Immersion time $24 \mathrm{~h}$

\begin{tabular}{|c|c|c|c|c|c|c|c|}
\hline $\begin{array}{c}\text { Inhibitor } \\
\text { concentration }\end{array}$ & 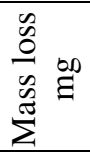 & $\begin{array}{c}\text { Inhibition } \\
\text { efficiency, } \\
\eta \%\end{array}$ & $\begin{array}{c}\text { Surface } \\
\text { coverage } \theta\end{array}$ & 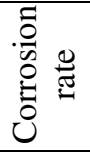 & $\begin{array}{l}\text { Corrosion } \\
\text { current }\end{array}$ & $\begin{array}{c}\text { Rate } \\
\text { constant }\end{array}$ & $\begin{array}{l}\text { Half } \\
\text { life }\end{array}$ \\
\hline Uninhibited & 98.5 & 0.00 & 0.0000 & 6.10 & 196178.47 & 0.0056 & 124.19 \\
\hline \multicolumn{8}{|l|}{ Leaf extract } \\
\hline 0.12 & 49.7 & 49.54 & 0.4954 & 3.08 & 98985.48 & 0.0027 & 254.58 \\
\hline 0.24 & 39.5 & 59.90 & 0.5990 & 2.45 & 78670.55 & 0.0021 & 322.51 \\
\hline 0.36 & 32.7 & 66.80 & 0.6680 & 2.02 & 65127.27 & 0.0018 & 391.33 \\
\hline
\end{tabular}




\begin{tabular}{cccccccc}
\hline 0.48 & 22.7 & 76.95 & 0.7695 & 1.41 & 45210.67 & 0.0012 & 567.43 \\
0.60 & 15.5 & 84.26 & 0.8426 & 0.96 & 30870.72 & 0.0008 & 834.91 \\
Seed extract & & & & & & & \\
0.12 & 45.6 & 53.71 & 0.5371 & 2.82 & 90819.68 & 0.0025 & 278.23 \\
0.24 & 39 & 60.41 & 0.6041 & 2.41 & 77674.72 & 0.0021 & 326.75 \\
0.36 & 33.4 & 66.09 & 0.6609 & 2.07 & 66521.43 & 0.0018 & 382.95 \\
0.48 & 29.5 & 70.05 & 0.7005 & 1.83 & 58753.96 & 0.0016 & 434.70 \\
0.60 & 20.6 & 79.09 & 0.7909 & 1.28 & 41028.19 & 0.0011 & 626.13 \\
Bark extract & & & & & & & \\
0.12 & 45.6 & 53.71 & 0.5371 & 2.82 & 90819.68 & 0.0025 & 278.23 \\
0.24 & 39 & 60.41 & 0.6041 & 2.41 & 77674.72 & 0.0021 & 326.75 \\
0.36 & 33.4 & 66.09 & 0.6609 & 2.07 & 66521.43 & 0.0018 & 382.95 \\
0.48 & 29.5 & 70.05 & 0.7005 & 1.83 & 58753.96 & 0.0016 & 434.70 \\
0.60 & 20.6 & 79.09 & 0.7909 & 1.28 & 41028.19 & 0.0011 & 626.13 \\
Root extract & & & & & & & \\
0.12 & 45.3 & 54.01 & 0.5401 & 2.80 & 90222.18 & 0.0025 & 280.13 \\
0.24 & 38.4 & 61.02 & 0.6102 & 2.38 & 76479.73 & 0.0021 & 331.99 \\
0.36 & 32.5 & 67.01 & 0.6701 & 2.01 & 64728.94 & 0.0018 & 393.79 \\
0.48 & 24.6 & 75.03 & 0.7503 & 1.52 & 48994.83 & 0.0013 & 522.96 \\
0.60 & 18.7 & 81.02 & 0.8102 & 1.16 & 37244.03 & 0.0010 & 690.60 \\
Gum extract & & & & & & & \\
0.12 & 44.3 & 55.03 & 0.5503 & 2.74 & 88230.52 & 0.0024 & 286.65 \\
0.24 & 35.4 & 64.06 & 0.6406 & 2.19 & 70504.75 & 0.0019 & 360.84 \\
0.36 & 30.5 & 69.04 & 0.6904 & 1.89 & 60745.62 & 0.0016 & 420.17 \\
0.48 & 24.6 & 75.03 & 0.7503 & 1.52 & 48994.83 & 0.0013 & 522.96 \\
0.60 & 16.7 & 83.05 & 0.8305 & 1.03 & 33260.72 & 0.0009 & 774.31 \\
\hline Table & & & & & & &
\end{tabular}

Table 4. Effect of extract of different parts of plants acacia Senegal on mass loss data for corrosion of mild steel in $1 \mathrm{~N} \mathrm{HCl}$ at $298 \pm 1 \mathrm{~K}$, Effective area of specimen: $7.50 \mathrm{~cm}^{2}$ Immersion time $24 \mathrm{~h}$

\begin{tabular}{|c|c|c|c|c|c|c|c|}
\hline $\begin{array}{c}\text { Inhibitor } \\
\text { concentration }\end{array}$ & 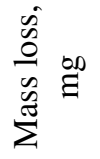 & $\begin{array}{c}\text { Inhibition } \\
\text { efficiency } \\
\eta \%\end{array}$ & $\begin{array}{c}\text { Surface } \\
\text { coverage, } \theta\end{array}$ & 葛 & $\begin{array}{l}\text { Corrosion } \\
\text { current }\end{array}$ & $\begin{array}{c}\text { Rate } \\
\text { constant }\end{array}$ & $\begin{array}{l}\text { Half } \\
\text { life }\end{array}$ \\
\hline Uninhibited & 129.2 & 0.00 & 0.0000 & 8.00 & 257322.42 & 0.0075 & 92.60 \\
\hline \multicolumn{8}{|l|}{ Leaf extract } \\
\hline 0.12 & 72.1 & 44.20 & 0.4420 & 4.46 & 143598.66 & 0.0040 & 172.83 \\
\hline 0.24 & 56.9 & 55.96 & 0.5596 & 3.52 & 113325.43 & 0.0031 & 221.29 \\
\hline 0.36 & 49.7 & 61.53 & 0.6153 & 3.08 & 98985.48 & 0.0027 & 254.58 \\
\hline 0.48 & 35.2 & 72.76 & 0.7276 & 2.18 & 70106.42 & 0.0019 & 362.94 \\
\hline 0.60 & 25.3 & 80.42 & 0.8042 & 1.57 & 50388.99 & 0.0014 & 508.26 \\
\hline \multicolumn{8}{|l|}{ Seed extract } \\
\hline 0.12 & 60.1 & 53.48 & 0.5348 & 3.72 & 119698.74 & 0.0033 & 209.05 \\
\hline 0.24 & 51.6 & 60.06 & 0.6006 & 3.19 & 102769.64 & 0.0028 & 244.89 \\
\hline 0.36 & 45.2 & 65.02 & 0.6502 & 2.80 & 90023.01 & 0.0025 & 280.77 \\
\hline 0.48 & 40 & 69.04 & 0.6904 & 2.48 & 79666.38 & 0.0022 & 318.37 \\
\hline 0.60 & 29.7 & 77.01 & 0.7701 & 1.84 & 59152.29 & 0.0016 & 431.71 \\
\hline
\end{tabular}




\begin{tabular}{cccccccc}
\hline Bark extract & & & & & & & \\
0.12 & 60.7 & 53.02 & 0.5302 & 3.76 & 120893.74 & 0.0033 & 206.90 \\
0.24 & 50.3 & 61.07 & 0.6107 & 3.11 & 100180.48 & 0.0028 & 251.44 \\
0.36 & 43.9 & 66.02 & 0.6602 & 2.72 & 87433.86 & 0.0024 & 289.34 \\
0.48 & 33.5 & 74.07 & 0.7407 & 2.07 & 66720.60 & 0.0018 & 381.79 \\
0.60 & 25.8 & 80.03 & 0.8003 & 1.60 & 51384.82 & 0.0014 & 498.24 \\
Root extract & & & & & & & \\
0.12 & 59.4 & 54.02 & 0.5402 & 3.68 & 118304.58 & 0.0033 & 211.62 \\
0.24 & 50.3 & 61.07 & 0.6107 & 3.11 & 100180.48 & 0.0028 & 251.44 \\
0.36 & 42.6 & 67.03 & 0.6703 & 2.64 & 84844.70 & 0.0023 & 298.43 \\
0.48 & 33.5 & 74.07 & 0.7407 & 2.07 & 66720.60 & 0.0018 & 381.79 \\
0.60 & 23.2 & 82.04 & 0.8204 & 1.44 & 46206.50 & 0.0012 & 555.02 \\
Gum extract & & & & & & & \\
0.12 & 60.7 & 53.02 & 0.5302 & 3.76 & 120893.74 & 0.0033 & 206.90 \\
0.24 & 47.8 & 63.00 & 0.6300 & 2.96 & 95201.33 & 0.0026 & 265.04 \\
0.36 & 41.3 & 68.03 & 0.6803 & 2.56 & 82255.54 & 0.0022 & 308.09 \\
0.48 & 36.1 & 72.06 & 0.7206 & 2.24 & 71898.91 & 0.0020 & 353.68 \\
0.60 & 27.1 & 79.02 & 0.7902 & 1.68 & 53973.98 & 0.0015 & 473.94 \\
\hline
\end{tabular}

The variation of reaction number with inhibitor concentration, presented graphically in (Figure 6-9), show reaction number decreases with increasing inhibitors concentration. Adsorption isotherm - Adsorption plays an important role in the inhibition of metallic corrosion by inhibitors. Many investigators have used the Langmuir adsorption isotherm to study inhibitors characteristics ${ }^{25}$.

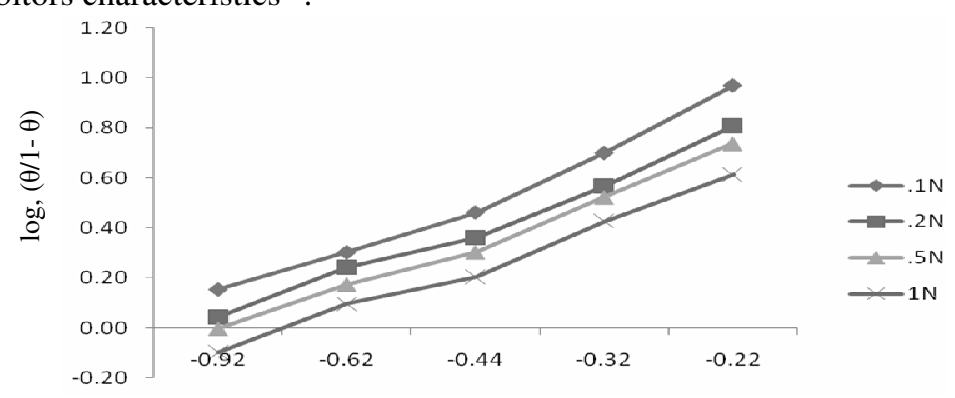

Log concentration, \% $/ \mathrm{V}$

Figure 5. Langmuir adsorption isotherm of leaves extract for mild steel in hydrochloric acid with inhibitor concentration

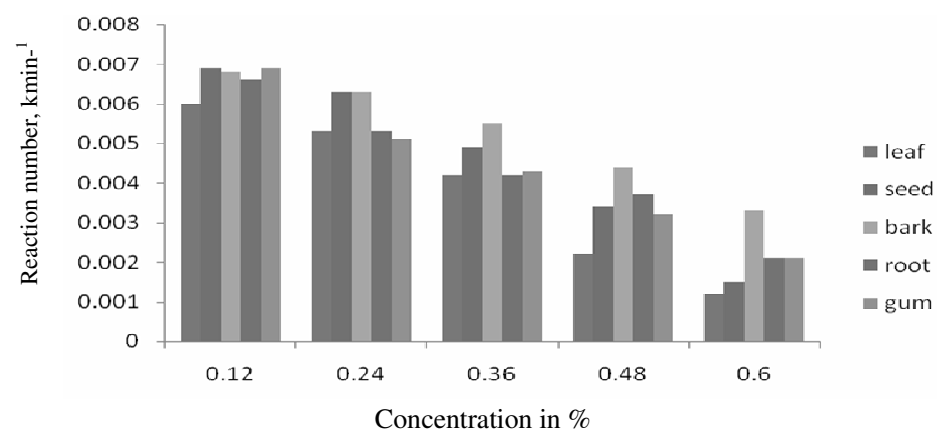

Figure 6. Variation of reaction number $v s$. Concentration with all five inhibitors in $2 \mathrm{~N}$ hydrochloric acid solution in mild steel 


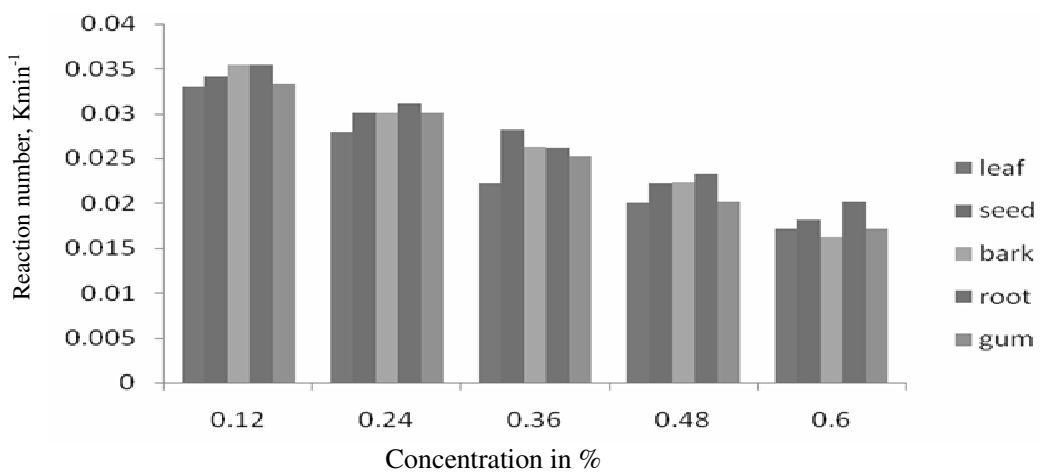

Figure 7. Variation of reaction number $v s$. Concentration with all five inhibitors in $3 \mathrm{~N}$ hydrochloric acid solution in mild steel

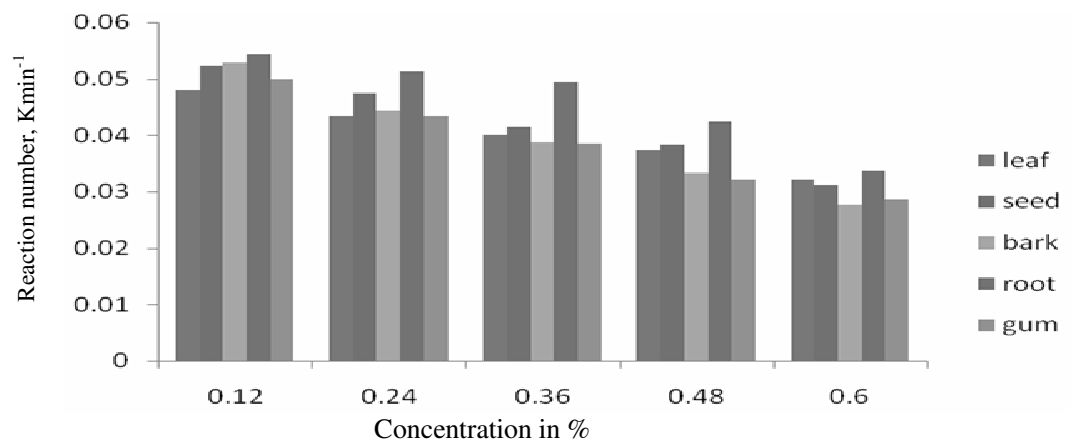

Figure 8. Variation of reaction number $v s$. Concentration with all five inhibitors in $4 \mathrm{~N}$ hydrochloric acid solution in mild steel

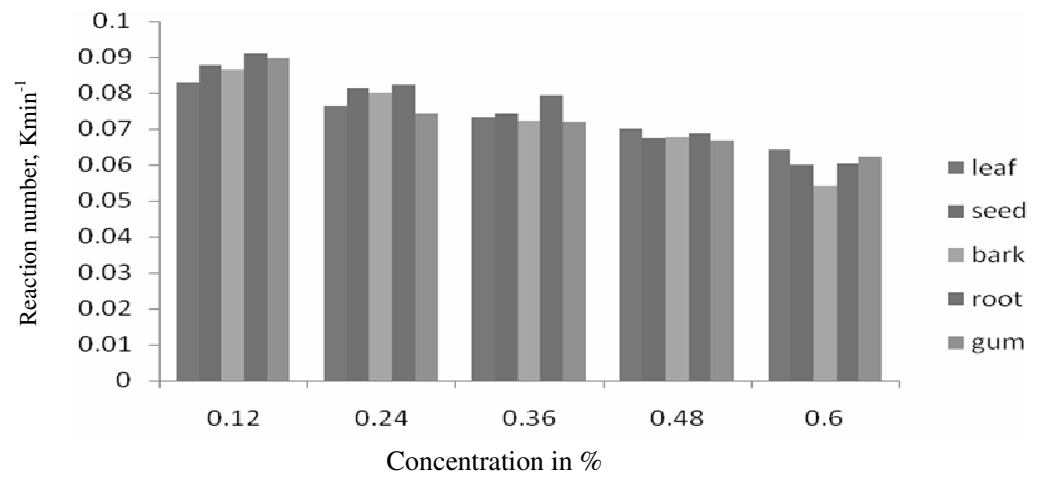

Figure 9. Variation of reaction number $v s$. Concentration with all five inhibitors in $5 \mathrm{~N}$ hydrochloric acid solution in mild steel

Langmuir adsorption isotherm-

$$
\log [\theta / 1-\theta]=\log A+\log C-(\theta / 2.3 R T)
$$

Should give a straight line of unit gradient for the plot of $(\theta / 1-\theta)$ versus $\log C$ where $\theta$ is surface coverage, $\mathrm{A}$ is a temperature independent constant and $\mathrm{C}$ is concentration of the inhibitor. The corresponding plot Figure 5 is linear but the gradients are not equal to unity as would be expected for the Langmuir adsorption isotherm equation. 
A wide range of substance can inhibit the corrosion of metal in aqueous acid solution. These include relative simple substance such as $\mathrm{C}, \mathrm{P}, \mathrm{Br}$ and I ions and many organic compounds, particularly those containing element such as N, O, S, P, As and Se. The primary step in the action of inhibition in acid solution in generally agreed to be adsorbed on the metal surface. Beside electrostatic interaction, inhibitor can bond to metal surface by electron transfer to the metal to form a co-ordinate type of link. This process is favored by the presence in the metal surface of vacant electron orbital of low energy, such as may be found in transition metal. Electron transfer from the adsorbed species is favored by the presence of loosely bound electrons, such as may be found in anions and neutral organic molecules containing lone pair of electron or II electron system associated with multiple bonds or aromatic rings. In organic compound suitable lone pair of electrons for co-ordinate bonding occur in functional groups containing elements $\mathrm{C}, \mathrm{N}, \mathrm{S}$. the tendency to stronger co-ordinate bond formation by these elements with decreasing electro negativity in the order $\mathrm{O}<\mathrm{N}<\mathrm{S}<\mathrm{Se}^{26-27}$ and depends also on the nature of the functional groups containing these elements. The structure of the rest of the molecule can affect co-ordinate bond formation by its influence on the electron density at the functional group ${ }^{28-30}$.

In the present study it is assuming that total alkaloids of the natural products are adsorbed on the metal surface and decrease the surface area available for cathodic and anodic reactions to take place.

\section{Acknowledgment}

The authors are thankful to the Head of chemistry Department, Government College, Ajmer for providing necessary laboratory facilities

\section{Conclusion}

The study of plant extract has shown them to be effective inhibitors of the corrosion of iron in acid solution. Both mass loss and thermometric determinations have shown that the inhibition efficiency increases with increasing inhibitor concentration over the range $0.12 \%-0.60 \%$ and with increasing acid concentration within the range $0.1 \mathrm{~N}$ to $5 \mathrm{~N}$ hydrochloric acid solution. Adsorption of these compounds on iron obeyed Langmuir adsorption isotherm. It is concluded that the plant extract of Acacia senegal is a good corrosion inhibitor for iron in acidic solution. This type of inhibitor are eco-friendly, biodegradable and less toxic therefore these type of inhibitors can be used to replace toxic chemicals

\section{References}

1. Uhlig H H, "Corrosion and Corrosion Control-An Introduction to Corrosion Science and Engineering". John Wiley and Sons, New York, 1971.

2. Liu G Q, Zhu Z Y, Ke W, Han E H and Zeng C L, Corros NACE, 2001, 57, 730 .

3. Collins W D, Weyers R E and Al Qadi I L, Corrosion NACE, 1993, 49, 1.74.

4. Ekpe U J, Ibok U J, Ita I B, Offiong O E and Ebenso E E, Mater Chem Phys., 1995, 40, 87.

5. Trabanelli G and Carassitl V, Advances in Corrosion Science and Technology, $\left(2^{\text {nd }}\right.$ Edn) Eds., M G Fontana and R W Satchel Plenum Press NY, 1976, 6.

6. El Hossary A A, Garwish M M and Saleh R M, Proc $2^{\text {nd }}$ Intl Symp Indl and Oriented Basic Electrochem Tech"Madars Prepr SAEST,CECRI Karaikudi, India, 1980, 6, 81.

7. The Useful Plants of India, CSRI New Delhi, The Wealth of India, CSIR New Delhi, 1986. 
8. EI Hossary A A, Saleh R M and Shams EI Din A M, Corros Sci., 1972, 12, 897.

9. Saleh R M and EI Hossary A A, Proc $13^{\text {th }}$ Seminar on Electrochem CECRI Karaikudi, India, 1972.

10. Sanghiav M J, Shukla S K, Misra A N, Padh M R and Mehta G N, Trans MFAI, 1996, 5, 143.

11. Zakvi S J and Mehta G N, Trans SAEST, 1998, 4, 23.

12. Chowdhary R, Jain T and Mathur S P, Bulletin of Electrochem., 2004, 20, 67

13. Quarishi M A, Rawat J and Ajmal M, Corrosion its Control Proc Int Conf Corros., 1997, 2, 634.

14. Taskawiec J, Sozanska M, Trzcionka B and Sukurczynska J, Koroz., 1995, 38, 249.

15. Shibad P R and Adhe K N, J Electrochem Soc India, 1981, 30, 103.

16. Shibad P R, J Electrochem Sos India, 1978, 27, 55.

17. Leung A Y, Encyclopedia of Common Natural Ingredients Used in Food, Drugs and Cosmetics. John Wiley \&Sons New York, 1980.

18. Duke J A and Wain K K, Medicinal Plant of the World, 1981, 3.

19. NAS, Firewood Crops Shrub and Tree Species for Energy Production Volume I. National Academy Press, Washington DC, 1980, 235.

20. Perjapati N D and Purohit S S, Sharma A K, Kumar T, A Hand Book of Medicinal Plants, Agrobios, India, 2003, 1, 238

21. Hugh Horning, George Langford, Roger Corneliussen and Lwewis H Reid, Amenex Metals and Material Consultants, 2004, 1, 5. URL: http://www.amenex.com/webpage/mnxhome.htm

22. Jones D A, Principles and Prevention of Corrosion, $2^{\text {nd }}$ Edn., 1996, 34.

23. Laxmi S, Chandra J R and Tainkili V, SAEST, 2004, 39, 127-131.

24. Stern M and Geary A L, J Electrochem Soc., 1987,104, 56.

25. Mfakins J R, J Appl Chem., 1963, 13, 330.

26. Papapanayiotou D, Nuzzo R N, Alkire R C, J Electrochem Soc., 1998, 145, 3366.

27. Yadav P N and Wadhwani R, Trans SAEST, 1993, 28, 134.

28. Gour B, Sing A K and Rao N J, Indian J Chem Technol., 1997, 2, 225.

29. Edwards B C, Corros Sci., 1969, 9, 395.

30. Brooks W B, Mate Prot., 1968, 7, 24. 


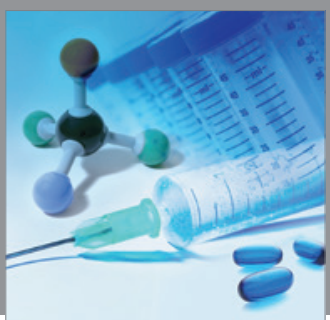

International Journal of

Medicinal Chemistry

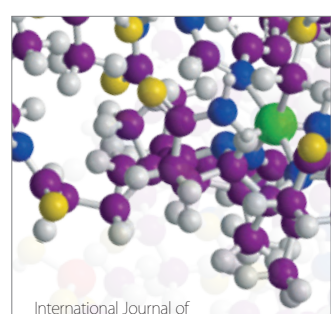

Carbohydrate Chemistry

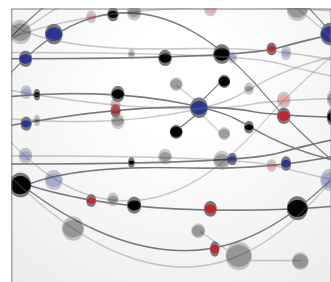

The Scientific World Journal
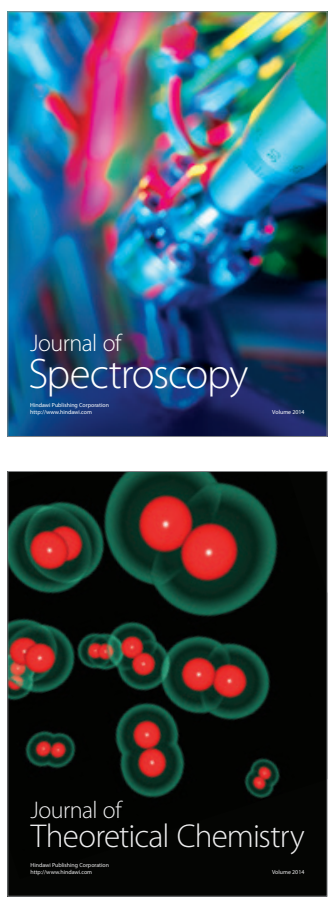
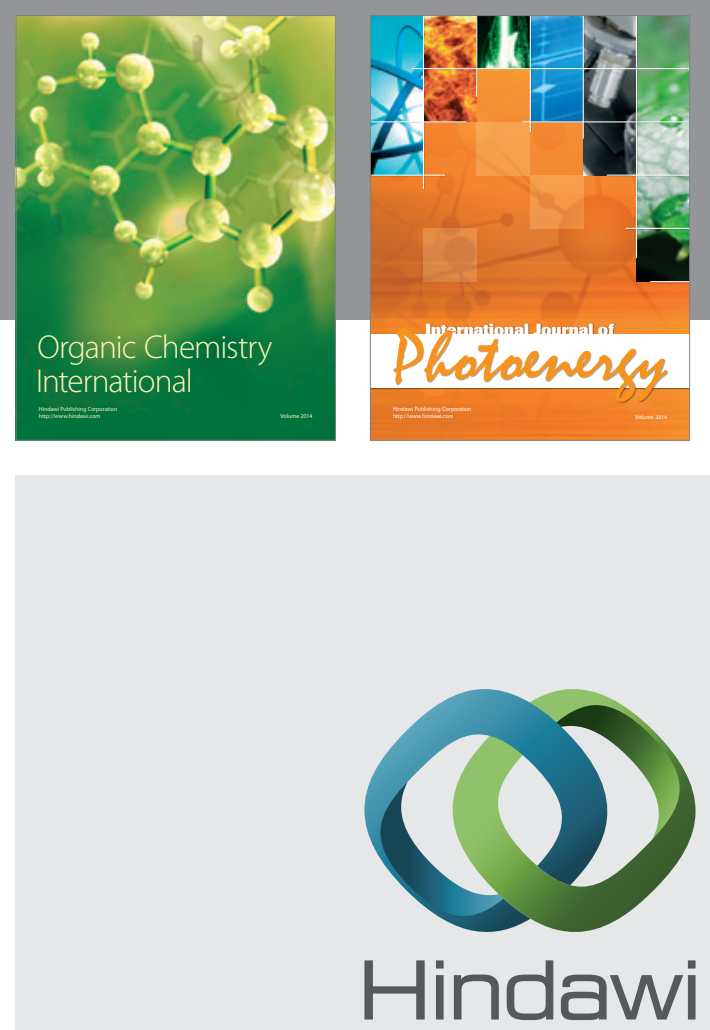

Submit your manuscripts at

http://www.hindawi.com
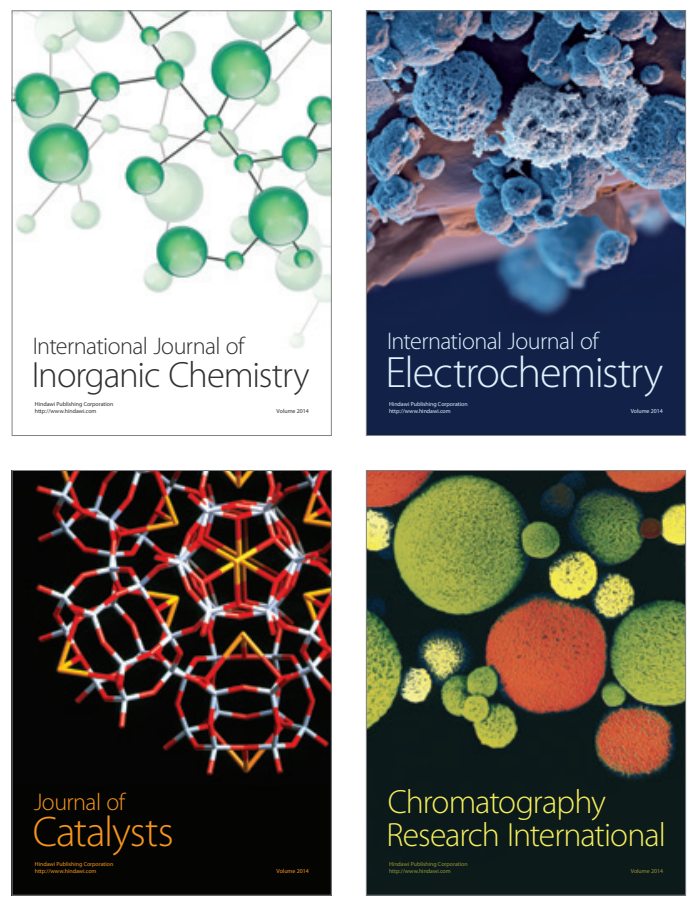
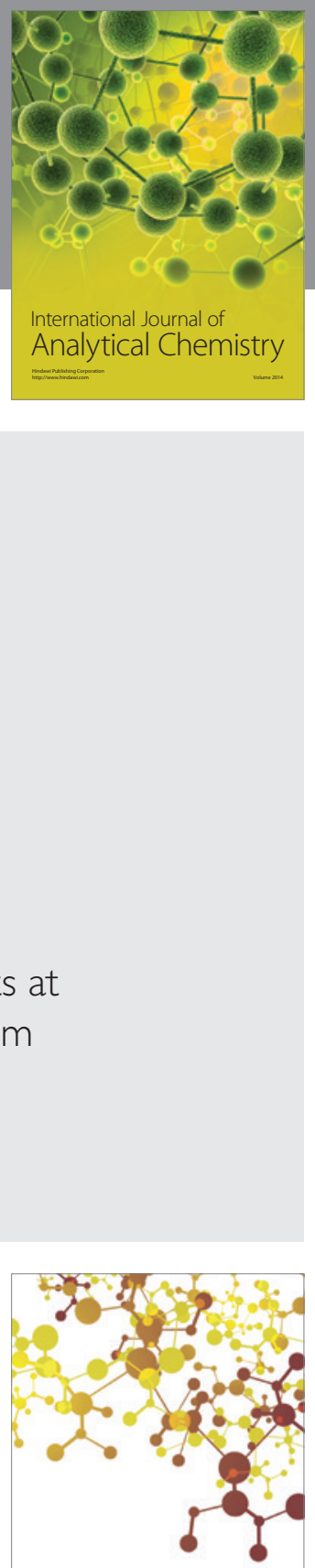

Journal of

Applied Chemistry
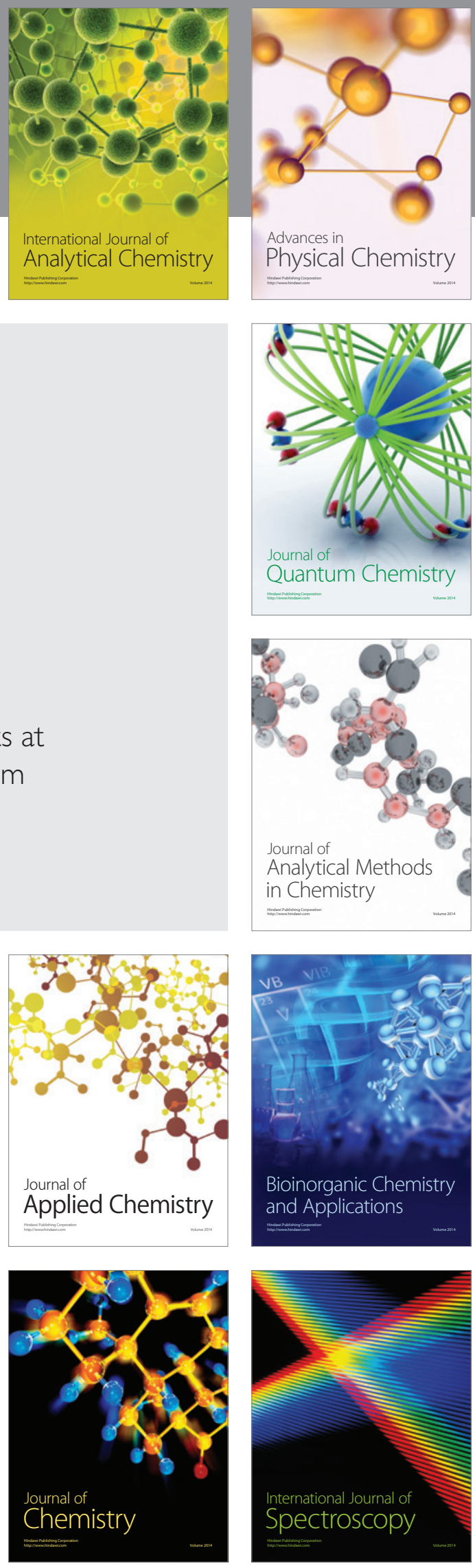